\title{
VALIDITAS PERANGKAT PEMBELAJARAN BERBASIS INKUIRI UNTUK MELATIHKAN KETERAMPILAN BERPIKIR KRITIS
}

\section{VALIDITY OF INQUIRY BASED LEARNING DEVICES TO TRAIN CRITICAL THINKING}

\author{
Flaviana Claudia Andayani \\ Program Studi Megister Pendidikan Sains, Universitas Negeri Surabaya, Indonesia \\ Email: flaviana.18004@mhs.unesa.ac.id
}

Diterima: 30 Juli 2020. Disetujui: 04 Agustus 2020. Dipublikasikan: 30 September 2020

\begin{abstract}
Abstrak: Keterampilan berpikir kritis merupakan keterampilan yang dituntut dalam menghadapi abad ke-21. Selain itu tuntutan kurikulum 2013 yang menekankan pembelajaran student center sehingga peserta didik harus mampu membangun pemahamannya sendiri berdasarkan pengalaman nyata. Keterampilan berpikir kritis dapat dilatihkan kepada peserta didik dengan model pembelajaran inkuiri yang difasilitasi melalui perangkat pembelajaran pada materi Jaringan Hewan karena pada materi tersebut terdapat tuntutan percobaan ilmiah yang dapat melatihkan peserta didik untuk menemukan masalahnya. Penelitian ini bertujuan untuk mendeskripsikan validitas Perangkat Pembelajaran berbasis inkuiri pada materi Jaringan Hewan untuk melatihkan keterampilan berpikir kritis peserta didik di SMA. Model pengembangan yang digunakan dalam penelitian ini adalah model 4-D yaitu define, design, develop dan disseminate, namun pada tahap disseminate tidak dilaksanakan. Perangkat pembelajaran yang dikembangkan terdiri dari RPP, BAPD, LKPD dan instrumen evaluasi. Berdasarkan hasil analisis validitas menggunakan pendapat Ratumanan dan Laurents dan analisis reliabilitas menggunakan percentage agreement didapatkan bahwa perangkat pembelajaran berbasis inkuiri untuk melatihkan keterampilan berpikir kritis pada materi Jaringan Hewan yang dikembangkan memiliki kriteria valid dan reliabel.
\end{abstract}

Kata Kunci: Perangkat Pembelajaran, Inkuiri, Keterampilan Berpikir Kritis, Validitas

\begin{abstract}
Critical thinking skills are skills required in the face of the 21st century. Besides, the 2013 curriculum demands that emphasize student center learning so students must be able to build their understanding based on real experience. Critical thinking skills can be trained to students with inquiry learning models that are facilitated through learning tools on Animal Tissue material because there is a demand for scientific experiments that can train students to find the problem. This study aims to describe the validity of inquiry-based Learning Tools on Animal Tissue material to practice students' critical thinking skills in high school. The development model used in this study is the 4-D model, which is defined, design, develop, and disseminate, but at the disseminate stage it is not implemented. The learning tools developed to consist of RPP, BAPD, LKPD, and evaluation instruments. Based on the results of the validity analysis using the opinion of Ratumanan and Laurents and reliability analysis using a percentage agreement found that the inquiry-based learning tool to practice critical thinking skills on Animal Tissue material developed has valid and reliable criteria.
\end{abstract}

Keywords: Devices Learning, Inquiry, Critical Thinking Skills, Validity

\section{PENDAHULUAN}

Pembelajaran biologi disekolah seharusnya sudah memberdayakan keterampilan berpikir kritis sehingga tujuannya peserta didik dapat mempersiapkan diri untuk menghadapi tantangan abad ke-21 [1]. Pada pembelajaran abad ke-21 memiliki tujuan dengan karekteristik 4C yaitu Communication, Critical Thinking and Problem Solving, Creativity and Innovation, dan Collaboration [2]. Oleh karena itu, pembelajaran biologi tidak boleh hanya sekedar mengingat dan memahami karena pembelajaran dengan sistem ini akan mengarah pada kemampuan menghafal materi [3]. Hal tersebut dapat diatasi dengan pembelajaran yang terintegrasi serta lebih mengarah kepada pengalaman secara langsung. Selain itu, Kurikulum yang digunakan pendidikan Indonesia saat ini adalah model kurikulum 2013, menekankan pada pembelajaran siswa aktif (student center). Pembelajaran dengan konsep student center, siswa diberikan kebebasan untuk membangun pemahamannya sendiri dan guru betindak sebagai fasilitator dalam kegiatan pembelajaran [4]. Pembelajaran yang dilakukan dengan memberikan ruang bagi siswa membangun pengetahuannya sendiri berdasarkan pengalaman nyata merupakan cara yang efektif untuk melatih siswa berpikir kritis dan analistis [5]. Dengan konsep student center, siswa mengetahui sumber pengetahuan itu di dapat sehingga pengetahuan yang diperoleh bermakna.

Terwujudnya pembelajaran bermakna diperlukan bahan ajar yang bersifat mengarahkan siswa untuk mendapatkan pengalaman belajar secara langsung. Bahan ajar merupakan salah satu sumber 
belajar, yang berfungsi memudahkan peserta didik memperoleh sejumlah informasi, pengetahuan, pengalaman, dan keterampilan dalam proses belajar mengajar [6]. Contoh bahan ajar adalah perangkat pembelajaran. Perangkat pembelajaran merupakan perangkat yang digunakan dalam proses pembelajaran [7]. Perangkat pembelajaran disusun untuk pendidik dan peserta didik yang digunakan dalam pembelajaran [8]. Perangkat pembelajaran berfungsi sebagai pedoman sehingga menjadi efektif dan efisien [7]. Bahan ajar yang berkualitas dapat menjadikan proses belajar lebih efektif, efisien, serta dapat meningkatkan mutu pembelajaran [9]. Sehingga perangkat pembelajaran yang digunakan juga harus menggunakan model pembelajaran yang dapat mendorong keterampilan berpikir kritis peserta didik. Dalam hal ini salah satu model yang dapat mendorong peserta didik untuk aktif dan membangun pengetahuan adalah model pembelajaran inkuiri.

Model Pembelajaran inkuiri menuntut peserta didik aktif untuk mencari dan menentukan konsep yang mereka butuhkan sehingga memperoleh pemahaman yang kuat terhadap materi yang dipelajari [10], khususnya pada materi Jaringan Hewan di SMA. Keterampilan berpikir kritis merupakan salah satu keterampilan berpikir tingkat tinggi yang menuntut peserta didik untuk mengunakan level kognitif tingkat analisis, evaluasi, dan mencipta [11]. Setiap sintak inkuiri membutuhkan keterampilan berpikir tingkat tinggi yaitu orientasi, merumuskan masalah, mengajukan hipotesis, mengumpulkan data, menguji hipotesis, dan merumuskan kesimpulan.

Menurut penelitian Hamdani [12] dan Susilawati [13], menyatakan bahwa dengan penggunaan bahan ajar berbasis inkuiri efektif untuk meningkatkan hasil belajar, keterampilan generik sains, penguasaan konsep serta melibatkan peserta didik aktif dalam menemukan konsep. Namun pada kenyataan pembelajaran Biologi masih dipahami secara tekstual yang seharusnya memerlukan kegiatan ilmiah sehingga peserta didik dapat mengembangkan keterampilan dan sikap ilmiah pada dirinya. Contohnya pada materi Jaringan Hewan kelas XI di SMA tidak dapat hanya sebatas dengan pengahafalan saja, melainkan harus dilakukannya kegiatan pengamatan langsung dan ilmiah untuk dapat memahami materi tersebut. Menurut Jufri [14] menjelaskan bahwa kemampuan bekerja secara ilmiah harus didukung oleh adanya rasa ingin tahu, kemampuan bekerjasama, dan keterampilan berpikir kritis. Sedangkan penelitian yang dilakukan Dewi [15] menyatakan bahwa kegiatan pembelajaran kelas, perangkat pembelajaran yang digunakan untuk melatihkan keterampilan berpikir kritis belum

Hasil dari penelitian ini berupa perangkat pembelajaran berbasis inkuiri untuk melatihkan keterampilan berpikir kritis pada materi jaringan diterapkan secara baik, sedangkan proses pembelajaran di Indonesia seharusnya dikembangkan menuntut siswa lebih aktif sehingga kemampuan berpikir kritisnya semakin berkembang dalam memecahkan masalah.

Berdasarkan uraian diatas mendorong dilakukannya penelitian ini dengan tujuan mengukur validitas perangkat pembelajaran yang terdiri dari RPP, LKPD, BAPD dan Instrumen evaluasi berbasis inkuiri untuk melatihkan keterampilan berpikir kritis pada materi Jaringan Hewan di SMA.

\section{METODE PENELITIAN}

Jenis penelitian ini merupakan penelitian dan pengembangan (Research and Development) yang digunakan untuk menghasilkan produk tertentu dan menguji keefektifan produk tersebut. Desain penelitian yang digunakan dalam penelitian ini adalah pengembangan model 4-D (Four D Models) menurut Thiagaran [16] yang terdiri dari tahap pendefinisian (define), perancangan (design), pengembangan (develop) dan penyebaran (disseminate). Akan tetapi bagian tahapan yang dilakukan dalam penelitian hanya sampai pada tahap development (pengembangan). Define merupakan tahapan yang menganalisis awal dan akhir hingga analisis tujuan pembelajaran. Design merupakan tahapan yang bertujuan untuk menentukan format hingga membuat rancangan awal perangkat pembelajaran. Development merupakan tahapan yang menghasilkan naskah akhir berupa perangkat pembelajaran yang terlebih dahulu di validasi

Uji kevalidan perangkat pembelajaran dilakukan oleh 2 validator yaitu ahli pendidikan biologi dan ahli materi biologi dengan cara mengisi lembar validasi. Data hasil validasi ahli dianalisis menggunakan pendapat Ratumanan dan Laurens [17] tingkat kevalidan ditentukan berdasarkan tabel beriku.

Tabel 1. Katagori hasil validasi

\begin{tabular}{cc}
\hline Interval & Kategori Penilaian \\
\hline $1.00 \leq \mathrm{SV} \leq 1.59$ & Tidak Valid \\
$1.60 \leq \mathrm{SV} \leq 2.59$ & Kurang Valid \\
$2.60 \leq \mathrm{SV} \leq 3.59$ & Valid \\
$3.60 \leq \mathrm{SV} \leq 4.00$ & Sangat Valid \\
\hline
\end{tabular}

Selanjutnya untuk mengukur kesepahaman validator menggunkan analisis percentage agreement [18]. Hasil validasi perangkat pembelajaran dikatakan reliabel jika percentage agreement $\geq 75 \%$ [19].

\section{HASIL DAN PEMBAHASAN}

hewan di SMA. Perangkat pembelajaran dapat digunakan dalam pembelajaran jika dikatagorikan valid dan reliabel. Proses pengembangan perangkat 
ini, sesuai dengan desain penelitian pengembangan model 4-D (Four D Models) menurut Thiagaran [16]. Tahap pengembangan terdiri dari 4 tahap [16] yaitu tahap pendefinisian (define) merupakan tahap untuk mendefinisikan, mengumpulkan informasi yang sesuai untuk produk yang dikembangkan terdiri dari pertama analisis awal dan akhir untuk menentukan masalah dasar dari materi jaringan hewan dengan cara menganlisis kurikulum. Kedua analisis peserta didik untuk menelaah gambaran karateristik siswa untuk disesuaikan dengan rancangan pengemabangan perangkat pembelajaran. Ketiga analisis tugas untuk mengidentifikasi keterampilan-keterampilan utama yang terdiri dari dua prosedur yaitu analis topic dan analisis prosedural. Keempat analisis konsep untuk menentukan isi materi yang dikembangkan. Kelima, analisis tujuan pembelajaran untuk merangkum hasil dari analisis konsep dan analisis tugas untuk menentukan perilaku objek penelitian. Hal ini sesuai juga dengan pendapat Zahroh [20] bahwa beberapa tahap yang dilakukan pada tahap define terdiri dari analis awal dan akhir, peserta didik, tugas, konsep, kurikulum serta analisis tujuan pembelajaran. Berdasarkan hasil analisis tahap define menunjukkan bahwa perangkat pembelajaran yang digunanakan pendidik adalah perangkat pembelajaran yang sudah disediakan sebelumnya, sehingga kurang sesuai dengan karakteristik siswa, tugas, kurikulum, tujuan pembelajaran. Hal ini sesuai dengan pendapat Dewi et al. [21] menyatakan bahwa penggunaan LKPD dan perangkat pembelajaran lain cenderung belum menfasilitasi peserta didik untuk menguasai materi dan berpikir tingkat tinggi.

Selanjutnya tahap kedua yaitu Design dilakukan empat tahap yaitu penyusunan standar tes, pemilihan media hal ini disesuaikan dengan karakterstik materi dan tujuan pembelajaran, pemilihan format yang menarik, memudahkan dan membantu siswa serta membuat rancangan awal sesuai dengan format yang ditetapkan [16]. Rancangan produk berupa RPP, LKPD, BAPD dan instrumen evaluasi. Peramgkat pembelajaran yang rancang berbasis inkuiri untuk melatihkan keterampilan berpikir kritis. Hasil prototype rancangan awal perangkat pembelajaran dijadikan sebagai drfaf I.

Tahap kegita adalah Development merupakan tahapan yang menghasilkan naskah akhir berupa perangkat pembelajaran yang terlebih dahulu divalidasi oleh ahli, terdiri dari 2 yaitu ahli materi biologi dan ahli pendidikan biologi, kemudian revisi perangkat (Draft II), uji coda sederhana, revisi perangkat (Draft III) dan produk akhir. Namun, peneliti membatasi sampai pada tahap validasi ahli. Kegiatan validasi ini untuk mengetahui tingkat kevalidan dan realibilitas peramgkat pembelajaran. Hasil analisis validitas dan reliabilitas dapat diamati pada tabel 1.2 berikut.

Tabel 2. Hasil Validasi Perangkat Pembelajaran

\begin{tabular}{clcccc}
\hline No & \multicolumn{1}{c}{ Perangkat Pembelajaran } & Rerata & Katagori & $\begin{array}{c}\text { Percentage } \\
\text { Agreement }\end{array}$ & Katagori \\
\hline 1 & RPP & 3.94 & Sangat Valid & $98.5 \%$ & Reliabel \\
2 & LKPD & 3.85 & Sangat Valid & $96 \%$ & Reliabel \\
3 & BAPD & 3.96 & Sangat Valid & $99 \%$ & Reliabel \\
4 & $\begin{array}{l}\text { Instrumen Evaluasi (Pretest dan } \\
\text { Posttest }\end{array}$ & 3.98 & Sangat Valid & $99.5 \%$ & Reliabel \\
\hline
\end{tabular}

Tabel 2 menunjukaan hasil rerata perangkat pembelajaran yang selanjutnya dianalisis katagori menurut Ratumanan dan Laurens [17] yang menghasilkan bahwa perangkat pembelajaran mempunyai skor $\geq 3.60$, yang artinya bahwa komponen perangkat pembajaran yang dikembangkan dikatagorikan sangat valid.

Perhitungan kesepakatan antar validator ahli diperoleh bahwa semua komponen perangkat pembelajaran yang dikembangkan memiliki percentage agreement $>75 \%$ atau dikategorikan reliabel. Berdasarkan hasil tersebut mengindikasi bahwa adanya konsistensi antar validator.

Komponen perangkat pembelajaran RPP diperoleh rerata 3.94 yang dikatagorikan sangat valid dan hasil percentage agreement $98.5 \%$ dikatagorikan reliabel. pada komponen RPP ini validasi dilakukan pada 8 kriteria yaitu identitas RPP, alokasi waktu, indikator pembelajaran, tujuan pembelajaran, materi pembelajaran, metode, sumber belajar, dan media, langkah-langkah pembelajaran dan penilaian. Implementasi RPP dilakukan pada 4 pertemuan. Dalam RPP langkah-langkah pembelajaran menggunakan metode inkuiri dan dipadukan dengan keterampilan berpikir kritis dimana guru hanya memeberikan panduan dan memtosivasi siswa berupa pertanyaan-pertanyaan selanjutnya siswa sendiri yang menemukan jawabannya sendiri. Hal ini sesuai dengan pendapat Ristanto [22] bahwa inkuiri terbimbing dimana guru hanya berperan dalam memberikan pertanyaan-pertanyaan dalam proses penemuan. Fase pembelajaran inkuiri terdiri atas 
menyajikan pertanyaan, membuat hipotesis, merancang percobaan, melakukan percobaan untuk memperoleh informasi, mengumpulkan dan menganalisis data, serta menarik kesimpulan [23]. Pembelajaran dengan metode inkuiri dapat membantu siswa untuk menemukan sendiri jawaban dari permasalahannya. Model pembelajaran inkuiri terbimbing memiliki pengaruh yang baik terhadap keterampilan berpikir kritis siswa [24] yang lebih menekankan pada proses pengolahan informasi, dimana siswa aktif mencari dan mengelolah sendiri informasi yang diperolehnya dengan tingkat proses mental yang lebih tinggi, sehingga siswa akan menemukan pengetahuan yang bermakna dan mengerti konsep dasar dan ide yang lebih baik [25]. Validasi RPP tidak lepas dari adanya saran dan masukan dari validator meliputi materi yang terdapat gambar harus disertai dengan adanya sumber yang jelas. Saran dari validator telah direvisi oleh peneliti.

Komponen perangkat pembelajaran LKPD diperoleh rerata 3.85 dikatagorikan sangat valid dengan percentage agreement $96 \%$ dikatagorikan reliabel. Penilaian LKPD terdiri dari kriteria isi dan penyajian. Menurut Darmojo dan Kaligis [26] LKPD yang baik memiliki syarat-syarat yang meliputi: syarat didaktik, syarat kontruksi dan syarat teknis. Syarat didaktik merupakan aspek isi dari LKPD yang terdiri dari kesesuaian kegiatan pembelajaran dengan tuntutan pelaksanaan pembelajaran berdasarkan kurikulum 2013, syarat kontruksi terdiri dari aspek kebahasaan karena tatacara berbahasa sangat penting untuk diperhatikan para peserta didik demi kelancaran komunikasi [27] sedangkan syarat teknis merupakan aspek penyajian. Dalam penelitian ini aspek kebahasaan yang merupakan syarat teknis dikategorikan dalam kriteria penyajian. LKPD yang dikembangkan berbasis inkuiri, sehingga tugas yang diberikan kepada siswa bukan hanya bersifat teoritis melainkan bersifat praktis sehinga tugas berhubungan dengan penyelidikan ilmiahLKPD berbasis inkuiri dikembangkan bertujuan untuk melatihkan keterampilan berpikir kritis siswa pada materi jaringan hewan di SMA. LKPD difasilitasi dengan kegiatan metode ilmiah berupa eksperimen agar memudahkan siswa dalam memahami materi jaringan hewan. Hapsari et al. [28] menjelaskan bahwa penyelidikan (ekperimen) merupakan kegiatan siswa dalam membangun konsep pengetahuan sendiri. Quing, et al., [29] dalam penelitiannya memberikan kesimpulan bahwa keterampilan berpikir kritis meningkat ketika pendekatan aktif seperti inkuiri eksperimen digunakan.

Berpikir kritis adalah kebiasaan pikiran ditandai dengan eksplorasi, komprehensif masalah, ide, artefak dan peristiwa sebelum menerima dan merumusakan masalah atau kesimpulan [30]. Sedangkan menurut Afrizon et al. [31] berpikir kritis adalah proses yang dilakukan seseorang dalam menyampaikan tujuan dengan alasan yang dibuat agar mempercayai suatu informasi yang diterima. Model inkuiri memiliki pengaruh yang baik dan tepat untuk keterampilan berpikir kritis. Kelebihan model pembelajaran inkuiri yaitu materi pelajaran akan mudah diingat, sehingga siswa tidak hanya menghafal tetapi dapat mengaplikasikannya secara langsung pada kehidupan sehari-hari siswa, serat dapat melatih kepercayaan diri siswa dalam menemukan sendiri inti dari setiap konsep tersebut, selain itu materi pembelajaran yang didapatkan oleh siswa akan lebih tahan lama, mudah diingat, dan bisa memunculkan motivasi belajar siswa sehingga siswa bisa mengikuti proses pembelajaran dengan baik [32]. Pembelajaran dengan metode inkuiri merupakan pembelajaran yang sesuai untuk melatihkan keterampilan berpikir kritis siswa karena dapat membantu guru dalam mengkaitkan materi pembelajaran dalam kelas dengan permasalahan yang terdapat di lingkungan, agar siswa menghubungkan pengetahuan yang telah diperoleh dengan menerapkannnya pada kehidupan sehari-hari sehingga materi yang disampaikan akan lebih bermakna bagi siswa [33]. Perangkat pembelajaran berupa LKPD untuk melatihkan keterampilan berpikir kritis siswa sesuai dengan penelitian Puspitadewi [34] dengan hasil kelayakan LKPD sebesar 96,5\% mampu membantu siswa dalam mempelajari dan meperoleh konsep materi serta dapat melatihkan kemampuan berpikir kritis. Validasi LKPD memiliki saran dan masukan dari validator meliputi mengubah ukuran gambar, menambahkan sumber gambar serta keterangan pada gambar. Saran dari validator telah direvisi.

Komponen perangkat pembelajaran BAPD memperoleh rerata 3.96 dan dikatagorikan sangat valid serta hasil percentage agreement sebesar 98.75\% dikatakagorikan reliabel. Validasi BAPD ini disusun memperhatikan tiga komponen utama yang meliputi komponen kelayakan isi, kelayakan penyajian, dan kelayakan kebahasaan. Sintak-sintak inkuiri sudah tersedia secara tepat dalam LKPD dan dapat melatihkan keterampilan berpikir kritis siswa yang mendapatkan pembelajaran dengan model inkuiri secara keseluruhan menunjukkan penguasaan konsep sainsnya lebih baik, karena semakin aktif peserta didik terlibat dalam pembelajaran akan semakin tinggi juga hasil belajar kognitif yang berbanding lurus dengan penguasaan konsep peserta didik [35]. Hal tersebut disebabkan karena dipengaruhi oleh langkah-langkah metode ilmiah yang diterapkan dalam pembelajaran dengan model inkuiri dapat melatih peserta didik untuk membangun sendiri pengetahuannya. Dalam BAPD tidak hanya berisi materi dan diskusi kelompok saja namun sudah memfasilitasi fitur-fitur seperti Biogame, analisis artikel, glosarium sehingga akan memudahkan siswa dalam memahami materi Jaringan Hewan. Fitur-fitur 
dalam BAPD tidak membosankan karena disajikan dengan gambar yang menarik serta tulisan yang sesuai dengan siswa SMA sehingga dapat melatihkan keterampilan berpikir kritis. Sesuai dengan pendapat Purwanto [36], gambar atau ilustrasi yang disajikan dapat digunakan untuk meningkatkan cara berpikir kritis dan kreatif peserta didik. Selain itu bahasa digunakan dalam BAPD sesuai dengan tata aturan Ejaan Yang Disempurnakan (EYD), serta tata bahasa yang digunakan telah disesesuaikan dengan bahasa nasional yang bersifat komunikatif sehingga siswa dapat memahaminya. Istilah yang digunakan telah sesuai dengan taraf berpikir siswa, istilah yang digunakan juga konsisten serta tidak mengandung makna ganda, petunjuk maupun arahan juga dinyatakan dengan jelas. Validasi BAPD memiliki saran dan masukan dari validator meliputi bahwa keterangan pada gambar menggunakan bahasa Indonesia bukan menggunakan bahasa asing. Saran dari validator telah direvisi.

Komponen perangkat pembelajaran instrumen evaluasi berupa pretest dan posttest memperoleh rerata 3,98 dan dikatagorikan sangat valid sedangkan hasil percentage agreement memperoleh skor 99,5\% dan dikatagorikan reliabel. Penilaian validasi instrumen evaluasi terdiri dari kriteria isi dan bahasa penulisan soal. Hasil ini mempresentasikan bahwa perangkat pembelajaran berupa instrumen evaluasi yang berbasis inkuiri dapat diimplementasikan dalam kegiatan pembelajaran untuk melatihkan keterampilan berpikir kritis. Soal pretest dan posttest juga sudah disesuaikan dengan KI dan KD pada materi Jaringan Hewan di SMA. Mengikuti aturan taksonomi bloom. Soal pretest dilakukan pada awal sebelum penerapan perangkat guna mengetahui pengetahuan awal siswa. Sedangkan soal posttest diimplementasikan pada akhir pembelajaran setelah diterapkan perangkat pemebelajaran untuk mengetahui perkembang keterampilan berpikir kritis siswa dampak dari perangkat pembelajaran yang digunakan.

Pengembangan perangkat berbasis inkuiri untuk melatihkan keterampilan berpikir kritis siswa di SMA juga dibuktikan dengan adanya penelitian dari Maryan et al [37] dengan hasil analisis data $(\mathrm{F}=$ 28.328; $\mathrm{p}=0.00<0.05)$ menunjukkan bahwa $\mathrm{H} 0$ ditolak dan Ha diterima, yang berarti model pembelajaran inkuiri berpengaruh terhadap keterampilan berpikir kritis siswa kelas XI MIA MAN 2 Mataram tahun ajaran 2019/2020.

\section{KESIMPULAN}

Perangkat pembelajaran dengan model inkuiri untuk melatihkan keterampilan berpikir kritis pada materi Jaringan Hewan yang dikembangkan memiliki tingkat validitas yang sangat valid dan reliabel. Sehingga mengindikasikan bahwa perangkat pembelajaran dapat diimplementasikan untuk kegiatan pembelajaran.

\section{DAFTAR PUSTAKA}

[1] Dahlia, D., Ibrohim, I., \& Mahanal, S. (2018). Peningkatan keterampilan berpikir kritis siswa SMP menggunakan perangkat pembelajaran berbasis inkuiri terbimbing dengan sumber belajar hutan wisata baning. Jurnal Pendidikan: Teori, Penelitian, Dan Pengembangan, 3(2), 188-194.

[2] Aisyah, N.E. (2017). "Strategi Pembelajaran Sains untuk Anak Prasekolah dan Sekolah Dasar Awal". Prosiding Seminar Nasional KSDP Prodi S1 PGSD.

[3] Septy, Y., Nur, W., \& Yuni, P. (2015). Peningkatan kemampuan berpikir kritis dengan pembelajaran berbasis scientific approach siswa kelas X SMA Panjura Malang. Jurnal Pendidikan Biologi Indonesia, 1(2), 240- 254.

[4] Ramadhani, H.S. (2017). Efektivitas metode pembelajaran scl (student centered learning) dan tcl (teacher centered learning) pada motivasi instrinsik \& ekstrinsik mahasiswa psikologi untag surabaya angkatan tahun 20142015. Persona: Jurnal Psikologi Indonesia, 6(2), 66-74.

[5] Yulianti, D. (2017). Problem-based learning model used to scientific approach based worksheet for phisics to develop senio high school students characters. Journal of Phisics: Conference Series, 824(1).

[6] Farda, J, U. Binadja, A.\& Purwanti, E. (2016). Validitas Pengembangan Bahan Ajar IPA Bervisi SETS. Journal of Primary Education. 5(1):36-41.

[7] Trianto. (2011). Mendesain Model Pembelajaran Inovatif- Progresif Konsep Landasan dan Implementasinya pada Kurikulum Tingkat Satuan Pendidikan (KTSP). Jakarta: Kencana

[8] Tanjung, H. S., dan Nababan, S. A. (2018). Pengembangan Perangkat Pembelajaran Matematika Berorientasi Model Pembelajaran Berbasis Masalah (Pbm) Untuk Meningkatkan Kemampuan Berpikir Kritis Siswa SMA SeKuala Nagan Raya Aceh. Genta Mulia: Jurnal Ilmiah Pendidikan, 9(2), 56-70

[9] Ningtyas, E, A., Sumarni, W., \& Christijanti, W. (2014). Pengembangan Modul IPA Terpadu Berbasis SETS Dengan Tema Hujan Asan Untuk Kelas VII SMP. Unnes Science Education Journal, 3(1): 438-444

[10] Novitaningrum, M. Parmin. \& Pamelasari, D, S. (2014). Pengembangan Handout IPA Terpadu Berbasis Inkuiri Pada Tema Mata Untuk Kelas IX Peserta didik MTs Al-Islam Sumurejo. Unnes Science Education Journal, 3(2):542-548. 
[11] Permana, T.I., Hindun, I., Rofi'ah, N.L., \& Azizah, A.S.N. (2019). Critical thinking skills: The academic ability, mastering concepts and analytical skill of undergraduate students. JPBI (Jurnal Pendidikan Biologi Indonesia) , 5(1), 1-8.

[12] Hamdani, F, V. (2017). Pengembangan Bahan Ajar Berbentuk LKS Berbasis Inkuiri untuk Meningkatkan Keterampilan Generik Sains dan Hasil Belajar Termokimia Siswa SMA. Pascasarjana. Unram.

[13] Susilawati., Susilawati., \& Sridana N. (2015). Pengaruh Model Pembelajaran Inkuiri Terbimbing terhadap Penguasaan Konsep Sains Ditinjau dari Kemampuan Awal Peserta didik. Journal Penelitian Pendidikan IPA, 1(2):102110.

[14] Jufri, A. W. (2013). Belajar dan Pembelajaran Sains. Bandung: Penerbit Pustaka Reka Cipta

[15] Dewi, R., Ege B., \& Syafruddin, D. (2018). Pengaruh model pembelajaran kooperatif tipe cooperative, integrated, reading, and composition berbasis media peta konsep terhadap kemampuan berpikir kritis siswa pada materi sistem pencernaan manusia. JPBIO (Jurnal Pendidikan Biologi) , 3(2), 31-40.

[16] Thiagarajan \& Sivasailam. 1974. Instructional Development for Training Teachers of Exceptional Children. Washinton DC: National Center for Improvement Educational System

[17] Ratumanan, G.T. \& Laurens, T. 2011. Evaluasi Hasil Belajar pada Tingkat Satuan Pendidikan. Surabaya: UNESA University Press

[18] Borich, G. D. 1994. Observation Skills For Effective Teaching. New York.

[19] Nasrah, N., Jasruddin, J., \& Tawil, M. (2017). Pengembangan Perangkat Pembelajaran Fisika Berbasis Pendekatan Contexstual Teaching And Learning (CTL) Untuk Memotivasi Dan Meningkatkan Hasil Belajar Fisika Peserta Didik Kelas VIII SMP Negeri 1 Balocci Pangkep. Jurnal Pendidikan Fisika-Journal of Physics Education, 5(2), 235-248

[20] Zahroh, S. M., \& Sudira, P. (2014). Pengembangan perangkat pembelajaran keterampilan generik komunikasi negosiasi siswa SMK dengan metode 4-D. Jurnal Pendidikan Vokasi, 4(3). 379-390.

[21] Dewi, S. M., Gunawan, G., Susilawati, S., \& Harjono, A. (2019). Validitas Perangkat Pembelajaran Fisika Berbasis Model Generatif Berbantuan Laboratorium Virtual. Jurnal Pendidikan Fisika dan Teknologi, 5(1), 162166.

[22] Ristanto, H.R. (2010). Pembelajaran berbasis inkuiri terbimbing dengan multimedia dan lingkunganriil ditinjau dari motivasi berprestasi dankemampuan awal (Tesis pascasarjana tidakdi publikasikan) Universitas Sebelas Maret.Surakarta

[23] Eggen, P and Kauchak, D. (2012). Strategi Dan Model Pembelajaran, Mengajarkan Konten Dan Keterampilan Berpikir. Jakarta : Indeks Permata Puri Media

[24] Lee, W. J., Puspitasari, K. A., Kim, H. Y., \& Jeong, A. (2010). The effects of guided inquiry questions on students' critical thinking skills and satisfaction in online argumentation. Online) (http://myweb. fsu. edu/ajeong/papers/Lee2010Inquiry Questions Argumentation. pdf, diakses 1 September 2016).

[25] Khotimah, Putri Chusnul. (2017). Pengembangan Lembar Kerja Siswa (Lks) Untuk Melatihkan Keterampilan Berpikir Kritis Peserta Didik Sman 4 Sidoarjo Pada Materi Kalor. Jurnal Inovasi Pendidikan Fisika (JIPF), 6(3) 295-300.

[26] Darmojo, Hendro., Jenny R.E Kaligis. 1993. Pendidikan IPA 2. Jakarta: Depdikbud

[27] Setyawati, R. 2013. Peranan bahasa Indonesia sebagai sarana membangun karakter bangsa. Sadhdhono, dkk. (Ed.). Proceending Seminar Internasional Pengembangan Peran Bahasa dan Sastra Indonesia Untuk Mewujudkan Generasi Berkarakter. Universitas sebelas maret, Surakarta 28-29 September 2013

[28] Hapsari, D., Sudarisman, S., \& Marjono. (2012). Pengaruh Model Inkuiri Terbimbing Dengan Diagram V (Vee) Dalam Pembelajaran Biologi Terhadap Kemampuan Berpikir Kritis Dan Hasil Belajar Siswa. Jurnal Pendidikan Biologi, 4 (3) Hal. 16-28.

[29] Quing, Z., Jing, G., \& Yan, W. (2010). Promoting Preservice Teacher Critical Thinking Skills by Inquiry Based Chemical Experiment. Procedia Social and Behavioral Sciences, 2(2010): 4597-4603.

[30] Colley B. M., Bilics A.R., dan Lerch, C.M. (2012). Reflection: A Key Component to Thinking Critically. The Canadian Journal for The Scholarship of Teaching and Learning, Vol 3(1).

[31] Afrizon, Renol., Ratnawulan., Fauzi, Ahmad. (2012). Peningkatan perilaku berkarakter dan keterampilan berpikir kritis siswa kelas ix mtsn padang pada mata pelajaran ipa fisika menggunakan model problem based instruction. Jurnal Penelitian Pembelajaran Fisika, Vol 1 $1-16$.

[32] Anam, R. (2015). Efektivitas dan pengaruh model pembelajaran inkuiri pada pembelajaran ipa di sekolah dasar. Mimbar Sekolah Dasar, 2(1), 78-85.

[33] Suryati dan Yuni, Permatasary. (2014). Pengembangan Pembelajaran Termokimia Berbasis Inkuiri Terbimbing Untuk 
J. Pijar MIPA, Vol. 15 No.4, September 2020: 366-372 DOI: $10.29303 /$ jpm.v15i4.2004

Meningkatkan Literasi Sains Siswa. Jurnal Pendidikan Kimia Hydrogen, 2(2)

[34] Puspitadewi, S. 2014. Pengembangan Lembar Kerja Siswa Materi Perubahan Lingkungan/Iklim dan Daur Ulang Limbah Berorientasi Kerikulum 2013 Untuk Melatihkan Berpikir Kritis Siswa. (Skripsi tidak dipublikasikan). Universitas Negeri Surabaya, Surabaya

[35] Susilawati., Susilawati., \& Sridana N. (2015). Pengaruh Model Pembelajaran Inkuiri Terbimbing Terhadap Penguasaan Konsep Sains Ditinjau Dari Kemampuan Awal Peserta
ISSN 1907-1744 (Cetak)

ISSN 2460-1500 (Online)

Didik. Journal Penelitian Pendidikan IPA, 1(2):102-110.

[36] Purwanto, J. \& Hasanah, B.U., (2014). Efektivitas Model Pembelajaran Inkuiri Tipe Pictorial Riddle Dengan Konten IntegrasiInterkoneksi Pada Materi Suhu Dan Kalor Terhadap Kemampuan Berpikir Kritis Peserta Didik SMA. Jurnal Inovasi Pendidikan Fisika, X(2), pp. 117-127

[37] Maryam, Kusmiyati, I Wayan Merta dan I Putu Artayasa. (2020). Pengaruh Model Pembelajaran Inkuiri Terhadap Keterampilan Berpikir Kritis Siswa. Jurnal Pijar MIPA. 15(3), 206-213. 